\title{
PERLINDUNGAN HUKUM TERHADAP DEBITUR YANG WANPRESTASI DALAM PEMBELIAN KENDARAAN RODA EMPAT
}

\author{
Legal Protection for Debtors who are in Default in Purchases Four-wheeled Vehicles \\ Pontianus Apa Rume Krowin ${ }^{1}$, Ruslan Renggong ${ }^{2}$, Baso Madiong ${ }^{2}$ \\ ${ }^{1}$ Magister Ilmu Hukum Program Pascasarjana Universitas Bosowa \\ ${ }^{2}$ Program Studi Ilmu Hukum Program Pascasarjana Universitas Bosowa \\ Email: pongkykrowin@gmail.com
}

Diterima: 12 Juli 2020/Disetujui: 07 Desember 2020

\begin{abstract}
ABSTRAK
Penelitian ini bertujuan untuk mengetahui (1) upaya hukum yang dapat ditempuh oleh debitur yang wanprestasi dalam pembelian kendaraan roda empat dan (2) pelaksanaan bentuk perlindungan hukum terhadap debitur yang wanprestasi dalam pembelian kendaraan roda empat. Penelitian ini menggunakan metode pendekatan empiris, wawancara, dan pengamatan. Populasi dan sampel dalam penelitian berjumlah 50 responden debitur dan seorang sebagai pengelolah hutang pada PT. Mandiri Tunas Finance. Data-data yang diperoleh dianalisis menggunakan analisis kualitatif dan akan dipaparkan secara lengkap. Hasil penelitian menunjukkan bahwa: (1) upaya hukum yang dapat di tempuh oleh debitur yang wanprestasi dalam pembelian kendaraan roda empat dapat ditempuh melalui pemberian surat teguran (somasi) dari kreditur, penjadwalan kembali atau perpanjangan waktu pembayaran (reschedulle), perundingan atau tawar-menawar kembali ke pihak kreditur untuk mencapai mufakat (negosiasi), penyelesaian masalah dengan melibatkan pihak ketiga yang bersifat netral sebagai pemediator (mediasi), dan mengupayakan penyelesaian akhir dengan membawa masalah ini ke pengadilan untuk diselesaikan secara hukum yang berlaku (litigasi). (2) Pelaksanaan bentuk perlindungan hukum terhadap debitur yang wanprestasi oleh Undang-undang No.8 tahun 1999 tentang perlindungan konsumen pasal 18 ayat 1 huruf a - g mengenai pelarangan pecantuman klausul baku oleh pelaku usaha, perlindungan terhadap debitur menurut otoritas jasa keuangan yaitu pelaku usaha dalam membuat format perjanjian tidak boleh menyertakan klausul yang merugikan debitur, dan perlindungan hukum terhadap nasabah menurut undang-undang perbankan yaitu pelarangan pembuataan format perjanjian kredit sepihak.
\end{abstract}

Kata Kunci : Perlindungan Hukum, Debitur, Wanprestasi, Pembelian, Roda Empat

ABSTRACT

This study aims to determine (1) legal measures that can be taken by debtors with default in the purchase of four-wheeled vehicles and (2) implementation of legal protection forms for debtors with default in purchasing four-wheeled vehicles. This type of research uses an empirical approach, interviews, observations, documentation studies. Populations and samples in the study were 50 debtor respondents and one as a debt manager at PT. Mandiri Tunas Finance. The results of the study show that: (1) legal measures that can be taken by debtors with default in the purchase of four-wheeled vehicles can be achieved through granting letters of reprimand (Subpoena) from the creditor, rescheduling or extension of payment (Reschedule), rescheduling or bargaining again to the creditor to reach a consensus (negotiation), resolving the problem by involving a neutral third party as a mediator (Mediation), and seeking a final settlement by bringing this matter to court for legal settlement (litigation). (2) Implementation of the form of legal protection for debtors no. 8 of 1999 concerning consumer protection Article 18 paragraph 1 letter $a-g$ concerning the prohibition of inclusion of standard clauses by business actors, protection of debtors according to the financial services authority, namely business actors in drafting an agreement may not include clauses that harm the debtor, and legal protection for customers according to banking law, which prohibits the formulation of a unilateral credit agreement format.

Keywords: Legal Protection, Debtors, Default, Purchases, Four Wheeled Vehicles

\section{PENDAHULUAN}

Pada saat ini, kebutuhan financial di masyarakat, khususnya negara berkembang semakin meningkat, mengingat semakin meningkatnya juga mobilitas dan aktivitas masyarakat. Segala aspek dalam kehidupan masyarakat pun tidak terlepas dari transaksi perbankan (Hermansyah, 2005). Kebutuhan masyarakat akan pembiayaan saat ini semakin tinggi, sehingga mengakibatkan semakin banyak pula lembaga keuangan baik itu bank maupun lembaga keuangan bukan bank yang 
menjadi tujuan dari masyarakat untuk memenuhi kebutuhan khususnya pembiayaan, baik itu pembiayaan dalam bentuk penyediaan dana maupun barang modal. Dalam hukum pembiayaan di Indonesia terdapat bermacam-macam bentuk lembaga pembiayaan, salah satunya adalah lembaga pembiayaan konsumen. Yang dimaksud dengan pembiayaan konsumen adalah kegiatan pembiayaan untuk pengadaan barang berdasarkan kebutuhan konsumen dengan sistem angsuran atau kredit, yang bertujuan untuk membantu perorangan ataupun perusahaan dalam pemenuhan kebutuhan dan permodalan mereka, khususnya untuk pembelian kendaraan seperti mobil (Makkasau, at.al, 2019).

Seiring dengan perkembangan zaman, berkembanglah perusahaan pembiayaan yang menyediakan jasa kepada nasabah dalam bentuk pembayaran harga barang secara tunai kepada pemasok. Antara perusahaan pembiayaan dan konsumen harus ada lebih dahulu perjanjian pembiayaan yang sifatnya pemberian kredit. Sesuai Pasal 1313 KUHPerdata menyebutkan bahwa perjanjian adalah suatu perbuatan dimana satu orang atau lebih mengikatkan dirinya terhadap satu orang atau lebih. Hal ini merupakan peristiwa yang menimbulkan hubungan hukum antara orang-orang yang membuatnya sehingga dari perjanjian tersebut nantinya akan menimbulkan suatu perikatan. Usman (2001) mengatakan bahwa, kredit adalah penyedia uang atau tagihan yang dapat dipersamakan dengan itu, berdasarkan persetujuan atau kesepakatan pinjam meminjam antar bank dan pihak lain yang mewajibkan pihak peminjam untuk melunasi utangnya setelah jangka waktu tertentu dengan pemberian bunga. Kredit juga berarti meminjamkan uang atau pemindahan pembayaran, apabila orang menyatakan membeli secara kredit maka hal ini berarti si pembeli tidak harus membayarnya pada saat itu juga. Oleh karenanya dalam perjanjian, terlibat dua pihak yakni debitur dan kreditur. Kreditur adalah pihak yang memberikan pinjaman atau kredit kepada debitur. Sedangkan debitur adalah pihak yang meminjam atau menerima pinjaman dari kreditur. Dengan demikian maka, dalam hal perjanjian, masing masing pihak baik kreditur dan debitur masing-masing memiliki hak dan kewajiban yang seyoagianya dilaksanakan secara teratur sehingga perjanjian jual belia antara duabelah pihak bisa berjalan secara sempurna (Nasution, 2007).

Didalam KUHPerdata hubungan antara perikatan dengan perjanjian adalah bahwa perjanjian itu menghasilkan perikatan. Perjanjian adalah sumber dari perikatan, disamping adanya sumbersumber yang lainnya. Suatu perjanjian juga dinamakan suatu persetujuan, karna para pihak itu juga setuju untuk melaksanakan sesuatu yang diperjanjikan (Subekti, 2005).

Tujuan dari penelitian ini adalah untuk mengetahui upaya hukum yang dapat ditempuh oleh debitur yang wanprestasi dalam pembelian kendaraan roda empat dan untuk mengetahui pelaksanaan perlindungan hukum terhadap debitur yang wanprestasi dalam pembelian kendaraan roda empat.

\section{METODE}

Lokasi penelitian ini adalah PT. Mandiri Tunas Finance Makassar. Adapun pertimbangan pemilihan lokasi ini karena perusahaan pembiayaan adalah perusahaan pembiayaan yang paling banyak diminati oleh konsumen jika dibandingkan dengan perusahaan pembiayaan yang lain karena namanya sudah terkenal di kalangan masyarakat pencinta kredit kendaraan bermotor. Hal ini didukung dengan letak perusahaan pembiayaan ini sangat strategis sehingga dapat dijangkau oleh kalangan masyarakat jika ingin melakukan transaksi secara kredit. Adapun tipe penelitian yang digunakan adalah yuridis empiris. Pendekatan yuridis empiris digunakan untuk memberikan gambaran secara kualitatif tentang perlindungan hukum terhadap debitur yang wanprestasi dalam pembelian kendaraan roda empat. Dalam melakukan pendekatan ini, metode yang digunakan adalah metode kualitatif. Populasi dalam penelitian ini dibagi menjadi dua yaitu: debitur yang wanprestasi dalam pembelian kendaraan roda empat pada PT. Mandiri Tunas Finance serta seorang sebagai pengelolaan hutang (head collection) pada PT. Mandiri Tunas Finance. Sampel penelitian yaitu 50 responden debitur yang memiliki hubungan erat dengan objek penelitian.

Adapun jenis dan sumber data yang digunakan dalam penelitian ini dikelompokan ke dalam dua jenis yaitu data primer dan data skunder: Data Primer diperoleh diperoleh langsung dari responden yang ditetapkan sebagai sampel, berupa hasil wawancara (interview) dan daftar isian dalam angket (kuesioner). Data Sekunder adalah data atau dokumen yang diperoleh dari literatur, serta peraturan perundangundangan, arsip-arsip yang ada relevansinya dengan materi yang dibahas. Data sekunder terdiri dari bahan hukum primer, bahan hukum sekunder, serta bahan hukum tersier yang dikumpulkan berdasarkan topik permasalahan yang telah dirumuskan: Bahan hukum primer berupa KUHPerdata dan UUPKNomor 8 tahun 1999, bahan hukum sekunder, berupa hasil-hasil penelitian, internet, buku, artikel ilmiah dan lainlain danBahan hukum tersier, berupa kamus hukum dan KBBI.

Teknik pengumpulan data yang digunakan pada penelitian ini adalah: pengamatan (observasi) yaitu pengambilan data dengan melakukan pengamatan secara langsung ke lapangan guna mendapatkan data yang dibutuhkan baik itu data primer atau data sekunder, serta wawancara (interview) yaitu pengumpulan data yang dilakukan dalam bentuk tanya jawab secara langsung kepada kepala bagian Head Collection pada PT. Mandiri Tunas Finance dan seorang debitur, angket (kuesioner) yaitu pengumpulan data melalui penyebaran daftar pertanyaan kepada 50 responden dan juga dokumentasi yaitu pengumpulan data yang berkaitan dengan penelitian ini.

Data yang diperoleh dan dikumpulkan baik dalam data primer maupun data sekunder dianalisis secara. Analisis kualitatif dilakukan dengan jalan memberikan penilaian perlindungan hukum terhadap debitur yang wanprestasi, kemudian data dipaparkan secara deskriptif yaitu dengan cara menjelaskan, menguraikan dan menggambarkan permasalahan serta penyelesaiannya yang berkaitan erat dengan penelitian ini. Data yang diperoleh melalui kuesioner akan di analisis dengan menggunakan analisis tabulasi frekuensi dan presentase perhitungan.

\section{HASIL DAN PEMBAHASAN}

Hasil penelitian dapat disajikan dalam Tabel 1 sampai dengan Tabel 5., dibawah ini. 
Tabel 1

Surat Somasi Oleh Pihak Kreditur Sebelum Pelaksanaan

Penarikan Kendaraan Roda Empat Terhadap Debitur

\begin{tabular}{clcc}
\hline No & \multicolumn{1}{c}{ Uraian } & Frekwensi & Presentase (\%) \\
\hline 1. & $\begin{array}{l}\text { Pernah melakukan somasi } \\
\text { Tidak pernah melakukan }\end{array}$ & 26 & 48 \\
s. & & 52 \\
\hline & \multicolumn{1}{c}{ Jumlah } & 50 & 100 \\
\hline
\end{tabular}

Sumber: Data Primer 2019

Tabel 2

Reschedulle/ Penjadwalan Kembali/ Perpanjangan Jangka Waktu Perjanjian Kredit Kendaraan Roda Empat

\begin{tabular}{clcc}
\hline No & \multicolumn{1}{c}{ Uraian } & Frekwensi & Presentase (\%) \\
\hline 1. & $\begin{array}{l}\text { Mengupayakan } \\
\text { reschedulle }\end{array}$ & 31 & 62 \\
2. & $\begin{array}{l}\text { Tidak mengupayakan } \\
\text { reschedulle }\end{array}$ & 19 & 38 \\
\hline & \multicolumn{1}{c}{ Jumlah } & 50 & 100 \\
\hline
\end{tabular}

Sumber: Data Primer 2019

Tabel 3

Upaya Negosiasi Yang dilakukan Oleh Debitur Ketika Wanprestasi

\begin{tabular}{clcc}
\hline No & \multicolumn{1}{c}{ Uraian } & Frekwensi & Presentase (\%) \\
\hline 1. & Melakukan negosiasi & 43 & 86 \\
2. & $\begin{array}{l}\text { Tidak } \\
\text { negosiasi }\end{array}$ & 7 & 14 \\
\hline \multicolumn{2}{c}{ Jumlah } & 50 & 100 \\
\hline
\end{tabular}

Sumber: Data Primer 2019

Tabel 4

Upaya Mediasi Yang Dilakukan Ketika Wanprestasi

\begin{tabular}{clcc}
\hline No & \multicolumn{1}{c}{ Uraian } & Frekwensi & Presentase (\%) \\
\hline 1. & $\begin{array}{l}\text { Pernah melakukan mediasi } \\
\text { Tidak pernah melakukan } \\
\text { mediasi }\end{array}$ & 33 & 64 \\
Jumlah & 50 & 100 \\
\hline
\end{tabular}

Sumber: Data Primer 2019

Tabel 5

Litigasi Sebagai Langkah Yang Dilakukan Oleh Debitur Wanprestasi

\begin{tabular}{|c|c|c|c|}
\hline No & Uraian & Frekwensi & Presentase (\%) \\
\hline 1. & Melakukan upaya litigasi & 1 & 2 \\
\hline 2. & $\begin{array}{l}\text { Tidak melakukan upaya } \\
\text { litigasi }\end{array}$ & 49 & 98 \\
\hline & Jumlah & 50 & 100 \\
\hline
\end{tabular}

Sumber: Data Primer 2019

Berdasarkan hasil penelitian diatas dapat kita bahas bahwa satu hal yang harus disadari oleh para pihak dalam perjanjian kredit khususnya bagi pihak debitur, bahwa implikasi yuridis yang muncul dengan ditandatanganinya suatu perjanjian maka para pihak berkewajiban untuk mematuhinya. Artinya, perjanjian yang sudah ditandatangani mengikat kedua belah pihak. Secara normatif dalam KUHPerdata Pasal 1313 mengemukakan, suatu perjanjian adalah suatu perbuatan dengan mana satu orang atau lebih mengikatkan dirinya terhadap satu orang lain atau lebih. Selanjutnya dalam Pasal 1320 KUHPerdata menjelaskan untuk sahnya suatu perjanjian diperlukan 4 syarat yakni: sepakat mereka yang mengikatkan dirinya; kecakapan untuk membuat suatu perikatan; suatu hal tertentu dan suatu sebab yang halal. Sementara itu dalam Pasal 1338 ayat (1) menjelaskan, semua perjanjian yang dibuat secara sah berlaku sebagai undang-undang bagi mereka yang membuatnya.
Berdasarkan ketentuan tersebut diatas, bagi para pihak yang akan menandatangani suatu perjanjian khususnya perjanjian kredit perlu mempelajari dengan cermat apa hak dan kewajiban yang harus dipenuhi sebelum ditandatanganinya kontrak tersebut. Hal ini penting, mengingat dalam perjanjian kredit memuat syarat dengan klausul. Artinya ada sejumlah persyaratan yang harus dipatuhi oleh Debitur. Bila tidak dipatuhi akan mempunyai konsekuensi antara lain berupa denda yang tentunya dapat merugikan Debitur. Oleh karena itu, acapkali yang terjadi dalam suatu perjanjian kredit sebagai pihak Debitur merasa hak-haknya sebagai nasabah diabaikan begitu saja, padahal Debitur sendiri sudah menandatangani perjanjian tersebut. Dari sudut pandang Kreditur sendiri, Kreditur semata-mata hanya melaksanakan apa yang sudah menjadi kesepakatan bersama. Berbicara kreditur baik bank maupun pembiayaan ingin agar dana atau benda yang menjadi objek perjanjian kredit yang disalurkan ke Debitur kembali pada waktu yang sudah disepakati.

\section{Pelaksanaan Bentuk Perlindungan Hukum Bagi Debitur Yang} Wanprestasi

a. Pasal 18 Undang-undang Perlindungan Konsumen N0.8 Tahun 1999

Perlindungan Konsumen adalah segala upaya yang menjamin adanya kepastian hukum untuk memberi perlindungan kepada konsumen. definisi ini diharapkan dapat menjadi penghalang pelaku usaha untuk melakukan tindakan yang sewenag-wenang terhadap kepentingan konsumen. Namun bukan berarti UUPK menghilangkan kepentingan pelaku usaha, UUPK justru menumbuhkembangkan sikap jujur dan bertanggungjawab dari pelaku usaha dalam menjalankan usahanya sehingga dapat meningkatkan kualitas barang dan/atau jasanya untuk menjamin kesehatan, kenyamanan, keamanan dan keselamatan konsumen serta mendorong iklim berusaha yang sehat dan melahirkan perusahaaan tangguh dalam menghadapi persaingan melalui pelayanan dan penyediaan barang dan/atau jasa yang berkualitas. dinyatakan bahwa pelaku usaha dalam menawarkan barang dan/atau jasa yang ditujukan untuk diperdagangkan di larang membuat atau mencantumkan klausul baku pada setiap dokumen dan/atau perjanjian.

Maksud dari larangan pencantuman klausul baku adalah untuk menempatkan kedudukan konsumen agar setara dengan pelaku usaha yang didasarkan pada prinsip kebebasan berkontrak.berikut beberapa bunyi larangan pencantuman klausul baku oleh pasal 18 UUPK yang berkaitan dengan klausul yang ada draft perjanjian PT. Mandiri Tunas Finance sebagai berikut: Pasal 18 ayat (1) huruf a yang menyatakan "pengalihan tanggung jawab pelaku usaha" dan Pasal 18 ayat (1) huruf f yang menyatakan "memberi hak kepada pelaku usaha untuk mengurangi manfaat jasa atau mengurangi kekayaan konsumen yang menjadi obyek jual beli jasa".

Klausul baku yang tercantum didalam draft perjanjian PT. Mandiri Tunas Finance sebagai berikut:

1. Point 9 huruf $b$ peristiwa cedera janji dan akibat hukumnya "debitur wajib menyerahkan barang agunan kepada kreditur atau kreditur akan melakukan penarikan barang agunan sehubungan dengan perjanjian pembiayaan dan lampirannya.

2. Point 10 pengalihan hak dan kewajiban debitur dengan ini memberikan persetujuan kepada kreditur untuk 
sewaktu-waktu sesuai pertimbangan kreditur

mengalihkan setiap hak dan kewajibannya yang timbul dari perjanjian pembiayaan beserta lampirannya kepada pihak manapun juga.

Berdasarkan pembahasan diatas penulis dapat mengambil kesimpulan bahwa walaupun UU.N0.8 Tahun 1999 pasal 18 sudah melarang pelaku usaha untuk tidak menerapkan atau mencantumkan klausul baku di dalam draft perjanjian pada kenyataannya pelaku usaha didalam membuat format perjanjian pembiayaan masih menggunakan klausul baku. Hal ini justru memposisikan debitur ke keadaan hak yang lemah dan sangat merugikan debitur selaku pengguna fasilitas barang dan atau jasa.

b. Pelaksanaan Bentuk Perlindungan Hukum Terhadap

Debitur Menurut Otoritas jasa Keuangan (OJK)

Salah satu tujuan dibentuknya Otoritas Jasa Keuangan (OJK) adalah untuk melindungi kepentingan konsumen dan masyarakat dalam melakukan kegiatan dalam sektor jasa keuangan. Perlindungan konsumen yang diamanahkan kepada OJK disebutkan secara eksplisit dalam pasal 4 (c) UU N0. 21 Tahun 2011 tentang OJK yang dinyatakan sebagai berikut :"Bahwa OJK di bentuk dengan tujuan agar keseluruhan kegiatan di dalam sektor jasa keuangan mampu melindungi kepentingan konsumen dan masyarakat".

Perlindungan konsumen yang diberikan OJK di anggap penting mengingat begitu kompleknya aktivitas dalam sektor jasa keuangan. Perlindungan konsumen yang difasilitasi OJK dapat berupa tindakan pencegahan kerugian konsumen, pelayanan pengaduan konsumen dan pembelaan hukum (Pasal 28 s.d 30 UUOJK). Untuk menyediakan payung hukum yang kuat dalam memberi perlindungan kepada konsumen dalam sektor jasa keuangan. Dalam sektor jasa keuangan, yang dimaksud dengan konsumen adalah pihak-pihak yang menempatkan dananya dan/atau memanfaatkan pelayanan yang tersedia di lembaga jasa keuangan antara lain nasabah pada perbankan, pemodal di pasar modal, pemegang polis pada peransuransian, dan peserta pada dana pensiun, berdasarkan peraturan perundang- undangan di sektor jasa keuangan, adapun disebut sebagai dengan Lembaga jasa keuangan yang juga disebut dengan Pelaku Usaha Jasa Keuangan (PUJK) adalah Bank Umum, Bank Pengkreditan Rakyat, Perusahan Asuransi, Lembaga Pembiayaan, Perusahaan gadai dan Perusahaan Penjaminan, baik yang melaksanakan kegiatan usahanya secara konvensional maupun secara syariah.

Pada konteks perjanjian pembiayaan, dalam pelaksanaanya OJK juga melarang pembuatan perjanjian yang memuat klausul baku sebagai berikut:

1) Ketentuan perjanjian yang tidak mengecualikan pasal 1266 dan 1267 KUHperdata yang menyatakan bahwa pembatalan kontrak harus melalui pengadilan. Pengecualian pada pasal ini harus dinyatakan apabila tidak dinyatakan maka pembatalannya tidak dapat dilakukan secara sepihak.

2) Penarikan kendaraan karena tunggakan kredit Debitur yang tidak sesuai prosedur yang berlaku.

3) Menyatakan pengalihan tanggung jawab atau kewajiban PUJK kepada konsumen.

4) Menyatakan bahwa PUJK berhak menolak pengembalian uang yang telah di bayar oleh konsumen atas produk dan/atau layanan yang di beli.

5) Menyatakan pemberian kuasa dari konsumen kepada PUJK, baik secara langsung maupun tidak langsung, untuk melakukan segala tindakan sepihak atas barang yang diagunkan oleh konsumen, kecuali tindakan sepihak tersebut dilakukan berdasarkan peraturan perundang - undangan.

6) Mengatur tentang kewajiban pembuktian oleh konsumen, jika PUJK menyatakan bahwa hilangnya kegunaan produk dan/atau layanan yang di beli oleh konsumen, bukan merupakan tanggung jawab PUJK.

7) Memberi hak kepada Kreditur untuk mengurangi kegunaan produk dan/atau layanan atau mengurangi harta kekayaan konsumen yang menjadi objek perjanjian produk dan layanan.

8) Menyatakan bahwa konsumen tunduk pada peraturan baru, tambahan,lanjutan dan/atau perubahan yang dibuat secara sepihak oleh PUJK dalam masa konsumen memanfaatkan produk dan/atau layanan yang di belinya.

9) Menyatakan bahwa konsumen memberi kuasa kepada PUJK untuk pembebanan hak tanggungan, hak gadai, atau hak jaminan atas produk dan/atau layanan yang di beli oleh konsumen secara angsuran.

Berdasarkan penjelasan di atas terlihat jelas bahwa dalam pelaksanaan aturan perundang-undangan No.21 tahun 2011 tentang OJK sudah mengatur dengan jelas pelarangan kepada PUJK bahwa dalam hal membuat kontrak atau perjanjian di larang memuat klausul baku. Namun demikian pada praktek sehari-hari PT. Mandiri Tunas Finance dalam lampiran ketentuan perjanjian pembiayaan masih memuat klausul baku, tindakan ini jelas sangat merugikan hak debitur sebagai pengguna fasilitas. Dalam UU OJK, pengaturan tentang klausul baku tidak secara tegas seperti dalam UUPK, namun hanya terdapat dalam Pasal-pasal pada konteks perlindungan konsumen sebagaimana dimaksud dalam Pasal 28 huruf a, b, dan c yang memuat tindakan tegas pencegahan kerugian konsumen dan masyarakat. Lebih lanjut dalam Pasal 29, 30 dan 31 UU OJK menyatakan OJK melakukan pengaduan konsumen, untuk melindungi konsumen dan masyarakat OJK berwenang melakukan pembelaan hukum yang mana memerintahkan atau melakukan tindakan tertentu kepada lembaga non-bank untuk menyelesaikan pengaduan konsumen yang dirugikan.

Dari pembahasan diatas dapat penulis mengambil kesimpulan bahwa peranan OJK dalam pelaksanaannya untuk melindungi konsumen dan masyarakat dari ketidakadilan PUJK sudah sangat efektif hanya saja para pelaku usaha dalam hal ini lembaga non-bank dalam membuat format perjanjian tidak sesuai dengan amanah yang diperintahkan oleh Undang-undang yang berlaku.

c. Pelaksanaan perlindungan hukum terhadap debitur menurut undang-undang No. 10 tahun 1998 tentang perbankan

Perjanjian kredit merupakan perjanjian baku (Standard contract),dimana isi atau klausul perjanjian kredit tersebut telah dibakukan dan dituangkan dalam bentuk formulir (blangko), tetapi tidak terikat dalam suatu bentuk tertentu. Calon nasabah debitur tinggal membubuhkan tandatangannya saja apabila bersedia menerima isi perjanjian tersebut, tidak memberikan kesempatan kepada calon debitur untuk membicarakan lebih lanjut isi atau klausul yang diajukan pihak bank (Sutarno, 2004). Walaupun perjanjian baku diperlukan untuk memenuhi kebutuhan yang sifatnya praktis dan kolektif pada tahap ini kedudukan calon debitur sangat lemah, sehingga menerima saja syarat-syarat yang disodorkan oleh pihak bank, karena jika tidak demikian calon debitur tidak akan mendapatkan kredit yang dimaksud. 
Dalam praktik perbankan pada konteks perjanjian juga masih menggunakan klausul baku. Hal ini menyalahi peraturan UUPK dan OJK yang dimaksud, oleh karena itu debitur dalam perjanjian kredit bank diberikan wewenang oleh peraturan bank Indonesia (PBI) untuk penyelesaian pengaduan dan mediasi perbankan. Dalam bermitra bank selaku kreditur juga bertanggungjawab apabila nasabah mengalami kerugian dengan menangani dan menyelesaikan berbagai keluhan dan pengaduan nasabah untuk menghindari berlarutnya masalah yang terjadi. Pengaduan nasabah dilakukan dengan standard waktu yang ditentukan dan berlaku secara umum. Risiko yang terdapat dalam perjanjian kredit bank dapat dilihat dari dua sisi yaitu, risiko yang ditanggung oleh bank sebagai kreditur dan risiko yang ditanggung oleh nasabah selaku debitur. Risiko yang ditanggung bank sebagai kreditur dapat berupa Credit Risk, Strategic Risk, Regulatory Risk, Operating Risk, Commodity Risk, Human Resouces Risk, Dan Legal Risk. Sedangkan risiko yang ditanggung oleh nasabah debitur antara lain risiko yang ditanggung debitur karena bentuk dari perjanjian kredit bank yang baku (standard) sehingga debitur tidak dapat ikut menentukan isi perjanjian tersebut.Kedudukan yang berbeda antara bank dan nasabah debitur yakni dimana bank memiliki posisi tawar yang lebih kuat jika dibandingkan dengan nasabah debitur menyebabkan ketidakseimbangan dalam pembuatan perjanjian kredit bank. Hal ini disebabkan perjanjian kredit bank tersebut dibuat dalam bentuk yang baku (standard) oleh pihak bank sehingga isi dari perjanjian kredit baku tersebut lebih menguntungkan pihak bank sedangkan nasabah hanya dapat menerimanya.

Menurut penulis, yang perlu disadari oleh para pihak dalam perjanjian kredit bahwa implikasi yuridis yang muncul dengan ditandatanganinya suatu perjanjian maka para pihak berkewajiban untuk mematuhinya. Artinya, perjanjian yang sudah ditandatangani mengikat kedua belah pihak. Secara normatif dalam KUHPerdata Pasal 1313 mengemukakan, suatu perjanjian adalah suatu perbuatan dengan mana satu orang atau lebih mengikatkan dirinya terhadap satu orang lain atau lebih. Selanjutnya dalam Pasal 1320 KUHPerdata menjelaskan untuk sahnya suatu perjanjian diperlukan 4 syarat yakni: sepakat mereka yang mengikatkan dirinya; kecakapan untuk membuat suatu perikatan; suatu hal tertentu dan suatu sebab yang halal. Sementara itu dalam Pasal 1338 ayat (1) menjelaskan, semua perjanjian yang dibuat secara sah berlaku sebagai undang-undang bagi mereka yang membuatnya.

Berdasarkan ketentuan tersebut diatas, bagi para pihak yang akan menandatangani suatu perjanjian khususnya perjanjian kredit perlu mempelajari dengan cermat apa hak dan kewajiban yang harus dipenuhi sebelum ditandatanganinya kontrak tersebut. Hal ini penting, mengingat dalam perjanjian kredit memuat syarat dengan klausul. Artinya ada sejumlah persyaratan yang harus dipatuhi oleh Debitur. Bila tidak dipatuhi akan mempunyai konsekuensi antara lain berupa denda yang tentunya dapat merugikan Debitur. Oleh karena itu, acapkali yang terjadi dalam suatu perjanjian kredit sebagai pihak Debitur merasa hak-haknya sebagai nasabah diabaikan begitu saja, padahal Debitur sendiri sudah menandatangani perjanjian tersebut. Dari sudut pandang Kreditur sendiri, Kreditur semata-mata hanya melaksanakan apa yang sudah menjadi kesepakatan bersama. Berbicara kreditur baik bank maupun pembiayaan ingin agar dana atau benda yang menjadi objek perjanjian kredit yang disalurkan ke Debitur kembali pada waktu yang sudah disepakati.

\section{KESIMPULAN DAN SARAN}

Hasil penelitian dan pembahasan dapat disimpulkan bahwa upaya hukum yang dapat di tempuh oleh debitur yang wanprestasi adalah dengan cara: Somasi adalah teguran tertulis terhadap pihak yang dinilai lalai dalam pemenuhan prestasi. Tujuan dari pemberian somasi ini agar pihak yang dituju berkesempatan untuk berbuat sesuatu atau menghentikan suatu perbuatan sesuai dengan yang di tuntut. Reschedule (Perpanjangan jangka waktu atau penjadwalan kembali perjanjian) antara kreditur dan debitur untuk melunasi cicilan kredit tersebut. Negosiasi (berunding kembali antara kedua belah pihak untuk mencapai mufakat), Mediasi (dengan melibatkan pihak ketiga yang bersifat netral sebagai pemediator menengahi masalah), Litigasi (penyelesaian masalah dengan membawa kasus wanprestasi ke pengadilan). Pelaksanaan bentuk perlindungan hukum terhadap konsumen menurut ketentuan undang-undang perbankan indonesia kurang memadai dilihat dari bentuknya, umumnya perjanjian kredit perbankan menggunakan bentuk perjanjian baku (Standard contract). Dalam praktiknya bentuk perjanjiannya telah disediakan oleh pihak bank sebagai kreditur hanya mempelajari dan memahaminya dengan baik, perjanjian ini biasa disebut dengan perjanjian baku (standardd contract), dimana dalam perjanjian tersebut pihak debitur hanya dalam posisi menerima atau menolak tanpa ada kemungkinan untuk melakukan negosiasi atau tawarmenawar. Artinya kedudukan konsumen sebagai pemakai fasilitas cenderung lemah dalam membuat suatu perjanjian.

\section{DAFTAR PUSTAKA}

Hermansyah. (2005). Hukum Perbankan Nasional Indonesia. Jakarta: Prenada Media

Makkasau, A. K., Pattenreng, A. M. A., \& Hamid, A. H. (2019). The Role of Consumer Dispute Settlement Board in Providing Legal Protection in Makassar City. Indonesian Journal of Legality of Law, 1(1), 2026.

Nasution, Az. (2007). Hukum Perlindungan Konsumen: suatu pengantar. Jakarta: Diadit Media.

Subekti. (2005). Hukum Perjanjian. Jakarta: PT. Internasa.

Sutarno. (2004). Aspek-aspek Hukum Perkreditan Pada Bank. Bandung: CV. Alfa Beta

Usman, R. (2001). Aspek-aspek hukum perbankan di Indonesia. Gramedia Pustaka Utama.

Undang-undang Nomor 8 Tahun 1999 Tentang Perlindungan Konsumen, LN Tahun 1999 No 42 TLN 382.

Undang-undang Nomor 42 Tahun 1999 Tentang Jaminan Fidusia.

Putusan Mahkamah Agung Nomor 1664K/Pdt/2014.

Undang-undang Nomor 10 Tahun 1998 Tentang Perubahan atas Undang-undang Nomor 7 Tahun 1992 Tentang Perbankan, LN No 182 Tahun 1998, TLN No 3790.

Peraturan Presiden No 9 Tahun 2009 Tentang Lembaga Pembiayaan. 